\title{
Relation Between Dendrometric Variables and Growth Stress in Eucalyptus
}

\author{
Frederico José Nistal França ${ }^{1}$, Graziela Baptista Vidaurre ${ }^{2}$, Leif Nutto ${ }^{3}$, \\ Jupiter Israel Muro Abad ${ }^{4}$, Djeison Cesar Batista², Jordão Cabral Moulin ${ }^{5}$ \\ ${ }^{1}$ Department of Sustainable Bioproductst, Mississippi State University, Starkville/MS, USA \\ ${ }^{2}$ Departamento de Ciências Florestais e da Madeira, Universidade Federal do Espírito Santo - UFES, \\ Jerônimo Monteiro/ES, Brazil \\ ${ }^{3}$ Forest Investment Department, Unique Forestry and Landuse, Freiburg, Germany \\ ${ }^{4}$ Research and Development, Toba Pulp Lestari - TPL, Porsea/Sumatra, Indonesia \\ ${ }^{5}$ Departamento de Ciência e Tecnologia da Madeira, Universidade Federal de Lavras - UFLA, Lavras/MG, Brazil
}

\begin{abstract}
The objective of this study was to identify eucalyptus clones for the production of sawed timber based on dendrometric variables and longitudinal residual deformation (LRD), analyzing the correlation between these characteristics. 20 Eucalyptus grandis $\mathrm{x}$ Eucalyptus urophylla clones with 13 years of age were analyzed. The crown size, diameter at breast height (DBH) and bark thickness were measured. There was a significant difference between the clones for DBH, LRD and bark thickness. There was no significant correlation between DBH and DRL. The correlation was significant between $\mathrm{DBH}$ and crown size, its being possible to affirm that crown size affects the diametrical growth of trees. DBH and bark thickness were also significantly correlated, in so far as trees with a wider diameter possess thicker bark. It was possible to select clones with better potential for sawed timber production, that is to say, elevated DBH with a reduced LRD.
\end{abstract}

Keywords: breast height diameter, crown size, longitudinal residual deformation.

\section{INTRODUCTION}

Eucalyptus wood produced in Brazil is mainly used to produce cellulose pulp, charcoal and industrial firewood. The use of sawed eucalyptus timber in products with higher added-value (PHAV) is still restricted to a few companies, since it requires a differentiated management system to be able to generate adequate quality and size of logs. However, it is already understood that numerous species of the genus have the potential for this type of use, such as in furniture, flooring and decorative surfaces.

The use of Eucalyptus wood for PHAV's requires changes in the mode of forestry production, whereby traditional management (with rotation of around seven years) needs to be substituted for longer rotations, with the application of thinning and pruning, and taking into account wood properties for genetic improvement programs. Management aimed at the production of sawed timber results in logs with a wider diameter, greater yields and better quality wood, with a greater proportion of adult wood and heartwood, greater dimensional stability and mechanical resistance and a lower incidence of knots (Sella, 2001; Dias, 2005).

Growth stress is present in trees and is related to trunk equilibrium, supporting the weight of the crown and the action of external factors, such as the wind and slope of the ground. These stresses are more accentuated in hardwoods than in conifers. Eucalyptus wood belongs to the former group and presents high 
stress levels (Beltrame et al., 2012), therefore limiting the use of its logs in sawed timber production.

Studies from the literature report the existence of correlations between the formation of growth stress and dendrometric variables, such as breast height diameter (BHD), total height and the size and shape of the tree crown (Lemos, 2002; Nutto \& Touza Vázquez, 2006).

Therefore, it is important to understand the factors that influence levels of growth stress in eucalypt populations, so that we can manage forestry plantations with the aim of reducing growth stresses and selecting clones with a lower propensity to present defects.

The aim of this research was to identify Eucalyptus grandis $\mathrm{x}$ Eucalyptus urophylla clones for the production of sawed timber considering dendrometric variables and longitudinal residual deformation, to analyze the correlation between these characteristics.

\section{MATERIAL AND METHODS}

\subsection{Description of the local and material}

20 Eucalyptus grandis $\mathrm{x}$ Eucalyptus urophylla hybrid clones of 13 years of age were assessed, collected from an experimental plantation located in Alcobaça, Southern Bahia, which were planted in October, 2000. The trees from different clones were planted randomly, at a spacing of $3 \times 3 \mathrm{~m}$ and were neither pruned nor thinned.

The area is 10 hectares and is located at the geographical coordinates of $17^{\circ} 33^{\prime} \mathrm{S}$ and $39^{\circ} 22^{\prime}$, with an average altitude of $50 \mathrm{~m}$ and a predominant soil type of Podzolic Yellow Dystrophic. According the Köppen climate classification, the climate is hot and rainy tropical, with a predominantly "Af" type, with temperatures above $18{ }^{\circ} \mathrm{C}$ in the coldest month. The average annual precipitation was around $1.378 \mathrm{~mm}$.

\subsection{Dendrometric variables}

15 trees were sampled for each clone to measure the dendrometric variables. The evaluation of crown size was carried out using direct observation, and was classified qualitatively according to four different levels, receiving a score from 1 to $4: 1$ - small; 2 - average; 3 - large and with few branches; and 4 - large and dense.

The breast height diameter (BHD) was measured with the help of a tape measure at $1.30 \mathrm{~m}$ from the ground and bark thickness was determined from the north side of the trunk, at the height of the BHD, using a digital pachymeter $(0.01 \mathrm{~mm})$.

\subsection{Longitudinal residual deformation (LRD)}

Five trees were sampled for each clone to determine the LRD, which was measured in the BHD position, in the cardinal directions of north and south. This position was adopted due to ease of access and due to the possibility of comparison with other studies.

The measurement method for growth deformation recommended by the Centre de Coopération Internationale em Recherche Agronomique pour le Développement, Département dês Forêt (CIRAD-Fôret) was used, which primarily consists of measuring the LRD using the freeing of growth stresses in the evaluated region in the trunk, with the use of a digital comparator watch (strain gauge) according to the use by Fournier et al. (1994). The LRD values were determined in the absence of wind, to avoid overestimated readings, since with the movement of the trees the internal sustaining forces can oscillate, influencing the outcome.

\subsection{Statistical analysis}

Statistical analysis was carried out in a completely randomized fashion and the effect of the clones were verified by the application of the analysis of variance (ANOVA). Given a significant difference between the measures of the clones with the F test, the Scott-Knott test was adopted at a $5 \%$ level of significance. The relation between the evaluated variables was assessed using the Pearson correlation coefficient and its $\mathrm{P}$ value. The statistical tests were realized using SISVAR software (Sisvar, 2003).

\section{RESULTS AND DISCUSSION}

\subsection{Dendrometric variables and $L R D$}

Crown size measures, BHD, bark thickness and LRD in the north and south direction of the 20 Eucalyptus grandis $\mathrm{x}$ Eucalyptus urophylla hybrid clones evaluated can be found on Table 1.

The scores 2 and 3 were obtained with greatest frequency in the visual analysis of crown size. For the crown size variable, the statistical test was not carried out due to non-normality in the distribution of the 
Table 1. Average crown size values, DBH, bark thickness and north and south direction for Eucalyptus grandis $\mathrm{x}$ Eucalyptus urophylla hybrid clones.

\begin{tabular}{|c|c|c|c|c|c|}
\hline \multirow{2}{*}{ CLONE } & \multirow{2}{*}{ Crown size } & \multirow{2}{*}{ BHD $(\mathrm{cm})$} & \multirow{2}{*}{$\begin{array}{l}\text { Bark thickness } \\
(\mathbf{m m})\end{array}$} & \multicolumn{2}{|c|}{ LRD (mm) } \\
\hline & & & & North & South \\
\hline \multirow{2}{*}{ A } & 3.09 & $26.7 \mathrm{a}$ & $2.94 \mathrm{~b}$ & $0.079 \mathrm{Ba}$ & $0.091 \mathrm{Aa}$ \\
\hline & (26.89) & (12.29) & (15.29) & $(21.14)$ & (28.69) \\
\hline \multirow{2}{*}{ B } & 3.42 & $30.2 \mathrm{a}$ & $4.09 \mathrm{a}$ & 0.116 Aa & $0.098 \mathrm{Aa}$ \\
\hline & (19.57) & (11.92) & (17.77) & (21.16) & $(32.82)$ \\
\hline \multirow{2}{*}{ C } & 2.85 & 26.9 a & $4.26 \mathrm{a}$ & $0.100 \mathrm{Aa}$ & $0.089 \mathrm{Aa}$ \\
\hline & (40.18) & $(24.54)$ & $(23.26)$ & $(42.00)$ & $(26.53)$ \\
\hline \multirow[b]{2}{*}{ D } & 3.15 & $27.2 \mathrm{a}$ & $5.76 \mathrm{a}$ & $0.056 \mathrm{Ba}$ & $0.056 \mathrm{Ba}$ \\
\hline & $(31.30)$ & (21.45) & $(24.70)$ & $(36.96)$ & (43.59) \\
\hline \multirow{2}{*}{ E } & 2.33 & $27.7 \mathrm{a}$ & $4.94 \mathrm{a}$ & $0.083 \mathrm{Aa}$ & $0.073 \mathrm{Aa}$ \\
\hline & (52.49) & (23.51) & (23.12) & $(25.10)$ & $(48.71)$ \\
\hline \multirow{2}{*}{ F } & 3.08 & $29.3 \mathrm{a}$ & $4.07 \mathrm{a}$ & 0.094 Aa & $0.101 \mathrm{Aa}$ \\
\hline & (40.22) & $(20.90)$ & (17.82) & $(31.89)$ & (26.46) \\
\hline \multirow{2}{*}{ G } & 1.30 & $17.1 \mathrm{~b}$ & $2.60 \mathrm{~b}$ & $0.075 \mathrm{Ba}$ & $0.068 \mathrm{Ba}$ \\
\hline & $(75.00)$ & (23.77) & $(22.96)$ & $(44.04)$ & (17.14) \\
\hline \multirow{2}{*}{$\mathbf{H}$} & 2.00 & $25.2 \mathrm{~b}$ & $3.53 \mathrm{~b}$ & $0.088 \mathrm{Aa}$ & $0.085 \mathrm{Aa}$ \\
\hline & $(52.22)$ & $(27.26)$ & (25.91) & (19.96) & $(25.01)$ \\
\hline \multirow{2}{*}{ I } & 2.85 & $29.1 \mathrm{a}$ & $4.30 \mathrm{a}$ & 0.084 Aa & $0.116 \mathrm{Aa}$ \\
\hline & $(42.66)$ & (23.85) & $(31.82)$ & $(38.38)$ & (33.19) \\
\hline \multirow[b]{2}{*}{$\mathbf{J}$} & 2.62 & $28.1 \mathrm{a}$ & $5.22 \mathrm{a}$ & $0.047 \mathrm{Ba}$ & $0.037 \mathrm{Ba}$ \\
\hline & (39.91) & (17.38) & $(15.82)$ & $(14.74)$ & (11.75) \\
\hline \multirow{2}{*}{$\mathbf{K}$} & 2.87 & $29.3 \mathrm{a}$ & $5.07 \mathrm{a}$ & $0.050 \mathrm{Ba}$ & $0.042 \mathrm{Ba}$ \\
\hline & (39.26) & $(27.96)$ & (22.63) & $(26.57)$ & $(16.75)$ \\
\hline \multirow{2}{*}{$\mathrm{L}$} & 2.70 & $27.6 \mathrm{a}$ & $4.28 \mathrm{a}$ & $0.070 \mathrm{Ba}$ & $0.072 \mathrm{Ba}$ \\
\hline & $(40.38)$ & (27.11) & (25.89) & $(23.40)$ & $(15.28)$ \\
\hline \multirow{2}{*}{$\mathbf{M}$} & 2.79 & $25.3 \mathrm{~b}$ & $3.78 \mathrm{~b}$ & $0.103 \mathrm{Aa}$ & $0.111 \mathrm{Aa}$ \\
\hline & $(53.02)$ & (25.23) & (21.65) & (13.38) & $(27.41)$ \\
\hline \multirow{2}{*}{$\mathbf{N}$} & 1.67 & $20.3 \mathrm{~b}$ & $2.94 \mathrm{~b}$ & 0.085 Aa & $0.087 \mathrm{Aa}$ \\
\hline & (73.85) & $(30.76)$ & $(31.64)$ & $(19.42)$ & $(18.87)$ \\
\hline \multirow{2}{*}{ O } & 2.23 & $25.5 b$ & $4.19 \mathrm{~b}$ & 0.108 Aa & $0.056 \mathrm{Ba}$ \\
\hline & (55.37) & $(33.31)$ & (29.08) & $(28.27)$ & $(17.63)$ \\
\hline \multirow{2}{*}{$\mathbf{P}$} & 3.14 & 27.9 a & $3.40 \mathrm{~b}$ & $0.107 \mathrm{Aa}$ & $0.092 \mathrm{Aa}$ \\
\hline & (32.68) & $(9.63)$ & (19.78) & (19.34) & $(35.87)$ \\
\hline \multirow{2}{*}{ Q } & 3.00 & $28.2 \mathrm{a}$ & $3.81 \mathrm{~b}$ & 0.116 Aa & $0.083 \mathrm{Aa}$ \\
\hline & $(36.00)$ & $(18.20)$ & (21.11) & $(15.63)$ & (20.77) \\
\hline \multirow{2}{*}{$\mathbf{R}$} & 3.00 & $31.0 \mathrm{a}$ & $4.88 \mathrm{a}$ & $0.110 \mathrm{Aa}$ & $0.068 \mathrm{Ba}$ \\
\hline & (36.98) & (13.57) & $(25.82)$ & $(28.86)$ & (13.13) \\
\hline \multirow{2}{*}{$S$} & 1.09 & $20.5 b$ & $3.58 \mathrm{~b}$ & $0.089 \mathrm{Aa}$ & $0.087 \mathrm{Aa}$ \\
\hline & (27.64) & $(24.64)$ & $(26.71)$ & $(41.84)$ & $(56.76)$ \\
\hline \multirow{2}{*}{$\mathrm{T}$} & 1.21 & $18.6 \mathrm{~b}$ & $3.59 \mathrm{~b}$ & $0.059 \mathrm{Ba}$ & $0.050 \mathrm{Ba}$ \\
\hline & $(66.03)$ & (36.44) & $(32.51)$ & (54.98) & $(37.03)$ \\
\hline AVERAGE & 2.54 & 26.20 & 4.09 & 0.086 & 0.078 \\
\hline
\end{tabular}

Results between parentheses correspond to the coefficient of variation (\%); Measures followed by the same letter, upper case letter in the column and lower case in the line are not statistically different from each other, using the Scott-Knott test at $5 \%$ probability.

scores obtained from the trees studied. The B clone obtained five scores of 3 and six of 4 , being the clone that presented the highest values for crown size. Ten trees of clone $\mathrm{S}$ were evaluated receiving a score of 1 , being the lowest for crown size out of the clones studied.
The average BHD of the trees was $26.2 \mathrm{~cm}$ (minimum of $8.6 \mathrm{~cm}$ and maximum of $41.9 \mathrm{~cm}$ ). There was a significant difference between the BHD averages of the twenty clones, the clone $\mathrm{R}$ presented the highest absolute average for BHD $(31.0 \mathrm{~cm})$, however it did 
not differ significantly from the clones A, B, C, D, E, F, I, J, K, L, P and Q. The clone G showed the lowest absolute average $(17.1 \mathrm{~cm})$, however it did not differ significantly from the clones $\mathrm{H}, \mathrm{M}, \mathrm{N}, \mathrm{O}, \mathrm{S}$ and $\mathrm{T}$.

The BHD results are in agreement with the range presented in other studies and varied from 23 to $35 \mathrm{~cm}$ in Eucalyptus grandis with an age between 11 and 15 years and between 18 and $44 \mathrm{~cm}$ for BHD in hybrid Eucalyptus grandis x Eucalyptus urophylla trees with ages between 8 and 11 years (Lima et al., 2004; König, 2005; Beltrame et al., 2012).

The average bark thickness of trees was $4.09 \mathrm{~mm}$, with a maximum equal to $9.24 \mathrm{~mm}$ and a minimum equal to $1.78 \mathrm{~mm}$. A significant difference was found between clones for bark thickness averages, with the G clone showing the lowest absolute average $(2.60 \mathrm{~mm})$, however it did not differ statistically from the clones A, $\mathrm{H}, \mathrm{M}, \mathrm{N}, \mathrm{O}, \mathrm{P}, \mathrm{Q}, \mathrm{S}$ and $\mathrm{T}$. The highest absolute average was observed for the clone $\mathrm{D}(5.76 \mathrm{~mm})$, however it did not differ statistically from the clones B, C, E, F, I, J, K, $\mathrm{L}$ and $\mathrm{R}$. The range of the averages for bark thickness was below the result found by Beltrame et al. (2012), who obtained an average of around $8.00 \mathrm{~mm}$ in trees from the Eucalyptus genus at nine years of age.

LRD results varied between $0.037 \mathrm{~mm}$ and $0.116 \mathrm{~mm}$, and the averages in the north and south directions were equal to 0.086 and $0.078 \mathrm{~mm}$, respectively. There were no significant differences between the averages of the clones in north and south positions, which means that the growth stress manifested itself in a similar manner on the two sides of the trunk. Other authors also reported non-significant differences between the LRD results in different cardinal positions in Eucalyptus grandis $\mathrm{x}$ Eucalyptus urophylla trees at ages between eight and 15 years (Lima et al., 2004; Beltrame et al., 2012).
Despite being non-significant, the differences observed in the LRD readings in the north and south positions can be associated with the predominating environmental factors, such as competition for light or due to the effect of the wind (Schacht, 1998). Variation can also be associated with internal factors such as the constitution of trunk material and the proportion of juvenile wood (Beltrame et al., 2012).

The LRD averages of the twenty clones studied are within the range reported in other research, which presented LRD values between 0.020 to $0.650 \mathrm{~mm}$ in Eucalyptus grandis plantations, as well as in Eucalyptus grandis $\mathrm{x}$ Eucalyptus urophylla hybrid plantations, with ages between 6 and 14 years (Souza, 2002; Lemos, 2002; Lima et al., 2004; Cardoso et al., 2005; Trugilho et al., 2006; Gonçalves, 2006; Beltrame et al., 2012).

\subsection{Pearson correlation}

In Table 2, the Pearson correlation coefficient results are found, carried out on the dendrometric variables and the LRD of the 20 Eucalyptus grandis $\mathrm{x}$ Eucalyptus urophylla hybrid clones.

As can be seen on Table 2, the correlations between all the variables were positive. However, only the correlations between the crown size $\mathrm{x}$ BHD and the bark thickness $x$ BHD were significant ( $\mathrm{P}$-value $<0.05)$, which can also be observed in the Figures 1 and 2 . This result was expected because the phenomenon of photosynthesis occurs in the leaves of the tree, being responsible for the primary metabolism of the vegetation and for its growth in diameter and height. Other authors also obtained the same results for different eucalypt species (Biechele et al., 2009; Nutto \& Touza Vázquez, 2006; Nutto et al., 2006). For example,

Table 2. Pearson correlation coefficient for Eucalyptus grandis $\mathrm{x}$ Eucalyptus urophylla hybrid.

\begin{tabular}{|c|c|c|c|c|c|}
\hline & Crown size & BHD & LRD north & LRD south & Bark Thickness \\
\hline Crown size & 1 & & & & \\
\hline \multirow{2}{*}{ BHD } & 0.904 & \multirow{2}{*}{1} & & & \\
\hline & $(<0.001)^{\star}$ & & & & \\
\hline \multirow{2}{*}{ LRD north } & 0.2607 & 0.2364 & \multirow{2}{*}{1} & & \\
\hline & $(0.267)$ & $(0.316)$ & & & \\
\hline \multirow{2}{*}{ LRD south } & 0.2366 & 0.1310 & 0.6269 & \multirow{2}{*}{1} & \\
\hline & $(0.315)$ & $(0.582)$ & $(0.031)$ & & \\
\hline \multirow{2}{*}{ Bark Thickness } & 0.4551 & 0.6245 & 0.3105 & 0.4393 & \multirow{2}{*}{1} \\
\hline & $(0.044)$ & $(0.003)$ & $(0.183)$ & $(0.053)$ & \\
\hline
\end{tabular}

C.S.: Crown Size; BHD: Breast height diameter; LRD: Longitudinal residual deformation; B.T.: Bark Thickness. *: P Value. 

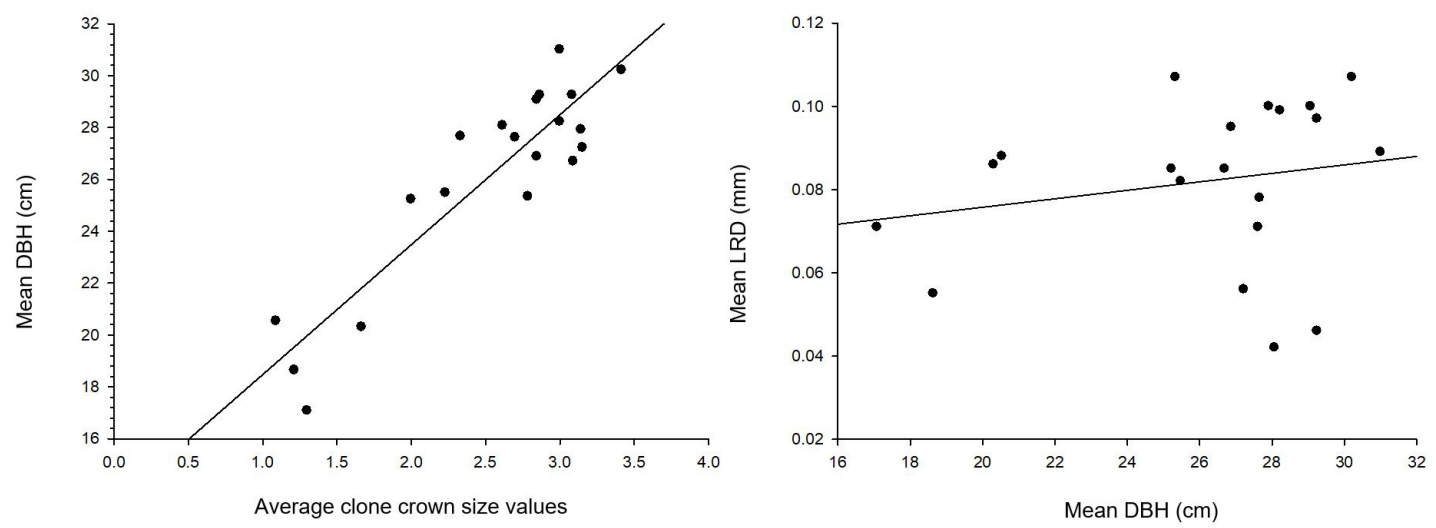

Figure 1. Scatter diagrams showing correlation between DBH x crown size.

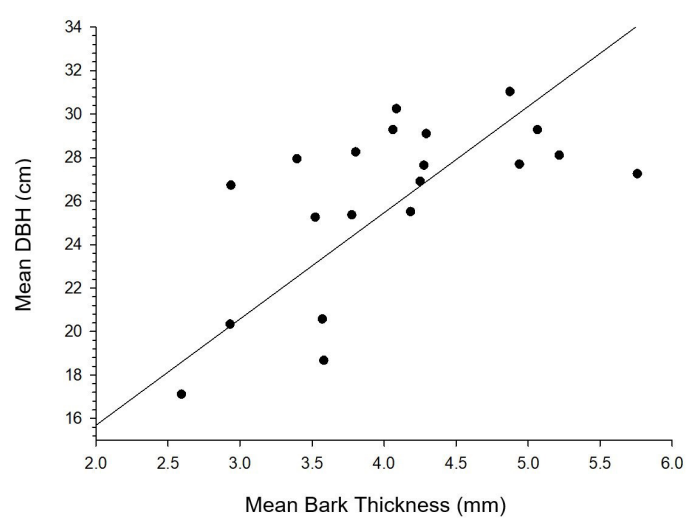

Figure 2. Scatter diagram of bark thickness x DBH.

König (2005) obtained $\mathrm{r}=0.799$ between BHD and width of the crown studying the Eucalyptus grandis $\mathrm{x}$ Eucalyptus urophylla hybrid planted in the states of Espírito Santo and Bahia.

According to the data presented in Table 2 and as observed in Figure 2, a positive and significant correlation was also observed between BHD x bark thickness. Clones with thinner bark are desirable, because the production of bark represents energy consumption by the plant, which could be utilized in the production of wood. Additionally, a greater quantity of bark also represents a greater volume of residue during the cutting of the logs and greater transportation costs.

The correlation observed between DBH and bark thickness differs from the results obtained by Beltrame et al. (2012), who studied clones from the Eucalyptus genus with nine years of age, encountering a negative correlation $(r=-0.359)$ and non-significant $(\mathrm{P}$-value $=0.01)$ between these variables.
A significant correlation between BHD and LRD was expected, which would be interesting from the point of view of indicating better genetic material, because the BHD is one of the most important dendrometric variables and is directly related to forestry production.

Low correlations and even non-significance between LRD and BHD were observed by a number of authors in Eucalyptus grandis and Eucalyptus grandis $\mathrm{x}$ Eucalyptus urophylla of different ages (Lima et al., 2004; Trugilho et al., 2007; Beltrame et al., 2012). These results indicated that the growth stresses are little affected by the growth rate of the tree (average annual growth).

\section{CONCLUSIONS}

The clones A, B, D, J, K, L and R were the most indicated for the provision of raw material for the production of cut timber because they presented greater BHD and lower LRD. These clones are recommended for the selection of material for future genetic improvement programs.

Trees with larger crowns showed greater diameter growth (BHD). Trees with greater diameters (BHD) presented thicker bark.

Significant correlations between LRD x BHD were not observed, indicating that they are independent characteristics in the selection process for trees for the production of sawed timber.

\section{ACKNOWLEDGEMENTS}

Fibria S.A. 


\section{SUBMISSION STATUS}

Received: 06 jan., 2015

Accepted: 05 may, 2017

\section{CORRESPONDENCE TO}

\section{Graziela Baptista Vidaurre}

Departamento de Ciências Florestais e da Madeira, Universidade Federal do Espírito Santo - UFES, Av. Governador Lindemberg, 316, Centro, CEP 29550-000, Jerônimo Monteiro, ES, Brazil e-mail: grazividaurre@gmail.com

\section{REFERENCES}

Beltrame R, Lazarotto M, Haselein CR, Santini EJ, Schneider PR, Aguiar AM. Determinação das deformações residuais longitudinais decorrentes das tensões de crescimento em Eucalyptus spp. Ciência Florestal 2012; 22(2): 343-351. http://dx.doi.org/10.5902/198050985741.

Biechele T, Nutto L, Becker G. Growth strain in Eucalyptus nitens at different stages of development. Silva Fennica 2009; 43(4): 669-679. http://dx.doi.org/10.14214/sf.187.

Cardoso AA Jr, Trugilho PF, Lima JT, Rosado SCS, Mendes LM. Deformação residual longitudinal em diferentes espaçamentos e idade em clones de híbridos de Eucalyptus. Cerne 2005; 11(3): 218-224.

Dias, AN. Um modelo para gerenciamento de plantações de eucalipto submetidas a desbaste [tese]. Viçosa: Programa de Pós-graduação em Engenharia Florestal, Universidade Federal de Viçosa; 2005.

Fournier M, Chanson B, Thibaut B, Guitard D. Mesures des déformations résiduelles de croissance à la surface des arbres, en relation avec leur morphologie. Observations sur différentes espèces. Annals of Forest Science 1994; 51(3): 249-266. http://dx.doi.org/10.1051/forest:19940305.

Gonçalves, FG. Efeito da taxa de crescimento na qualidade da madeira de híbrido clonal de Eucalyptus urophylla $x$ grandis para produtos sólidos [dissertação]. Alegre: Universidade Federal do Espírito Santo; 2006.
König C. Optimizing the production of high value timber in fast growing Eucalyptus plantation in Brazil (Aracruz Celulose S.A.) - Efficiency and Economic Impact of Pruning [dissertação]. Freiburg: Universidade de Freiburg; 2005.

Lemos F. Tensões de crescimento em Eucalyptus spp. e interações entre a taxa de crescimento, copa assimétrica e distribuição de tensões na superfície da raiz [dissertação]. Freiburg: Universidade de Freiburg; 2002.

Lima JT, Trugilho PF, Rosado SCS, Cruz CR. Deformações residuais longitudinais decorrentes de tensões de crescimento em Eucalyptus e sua associação com outras propriedades. Árvore 2004; 28(1): 107-116.

Nutto L, Spathelf P, Seling I. Management of individual tree diameter growth and implications for pruning brazilian Eucalyptus grandis Hill ex. Maiden. Floresta 2006; 36(3): 397-413. http://dx.doi.org/10.5380/rf.v36i3.7519.

Nutto L, Touza Vázquez MC. Modelos de producción de madera sólida en plantaciones de Eucalyptus globulus de Galicia. Boletin del CIDEU 2006, 2, 37-50.

Schacht L. Variação de caracteres e suas implicações para o melhoramento genético da madeira serrada de Eucalyptus urophylla [dissertação]. Piracicaba: Escola Superior de Agricultura "Luiz de Queiroz", Universidade de São Paulo; 1998.

Sella RL. Técnicas silviculturais e de exploração para a obtenção de madeira de qualidade para a laminação e serraria. In: Anais do Seminário Madeira de Eucalipto: Tendências e Usos; 2001; Curitiba. Curitiba: FUPEF; 2001, p. 19-24.

Sisvar. Sisvar versão 4.6 (Build 61) [online]. 2003. [cited 2014 Apr 23]. Available from: http://www.dex.ufla.br

Souza MAM. Deformação residual longitudinal (DRL) causada pelas tensões de crescimento em clones de híbridos de Eucalyptus [dissertação]. Lavras: Universidade Federal de Lavras; 2002.

Trugilho PF, Lima JT, Pádua FA, Soragi LC, Andrade CR. Deformação residual longitudinal (DRL) e tangencial (DRT) em seis clones de Eucalyptus spp. Cerne 2006; 12(3): 279-286.

Trugilho PF, Rosado SCS, Lima JT, Pádua FA, Souza MAM. Deformação residual longitudinal (DRL) e sua relação com as características de crescimento da árvore em clones de Eucalyptus. Cerne 2007; 13(2): 130-137. 